\title{
Characterization of Small Forest Landowners as a Basis for Sustainable Forestry Management in the Libertador General Bernardo O’Higgins Region, Chile
}

\author{
Francisca Ruiz-Gozalvo ${ }^{1}$, Susana Martín-Fernández ${ }^{2, * \mathbb{C}}$ and Roberto Garfias-Salinas ${ }^{1}$ \\ 1 Department of Forest Management and Environment, University of Chile, Santiago 11315, Chile; \\ franciscaruiz86@gmail.com (F.R.-G.); rgarfias@uchile.cl (R.G.-S.) \\ 2 Forestry School, Technical University of Madrid, 28040 Madrid, Spain \\ * Correspondence: susana.martin@upm.es; Tel.: +34-91-336-6401
}

Received: 22 October 2019; Accepted: 12 December 2019; Published: 16 December 2019

check for updates

\begin{abstract}
Sclerophyllous forests are extremely sensitive to global warming, and the sclerophyllous forest in the possession of small forest landowners (SFLs) in the Libertador General Bernardo O'Higgins Region in Chile is degraded in spite of their high ecological value. Due to the total lack of forest management, the yield obtained from native forests is very low, with highly intervened forests and intense soil erosion. The main contribution of this article is to present, for the first time, a study on the characterization and problems of 211 small forest landowners in this region of Chile. After interviewing the landowners, multivariate analysis techniques were applied to the results of the survey, which enabled four types of SFL to be identified. Differences were found in regard to the surface area of their properties and the products extracted, among others. However, they all had a similar social profile, low education level and little training in forest management, very advanced ages, a lack of initiative to create forest communities, and lack of basic services due to their isolation. The characterization of the SFLs allowed proposals to be designed for future sustainable forest management activities to help mitigate the continuous deterioration of the native forest and obtain products in a sustainable way and with greater yields, considering current legal aspects, access to subsidies, and specific forest training plans for each type of SFL.
\end{abstract}

Keywords: small forest landowner; sclerophyllous forest; sustainable forest management; multivariate analysis

\section{Introduction}

Sustainable forest management (SFM) is the most widely known type of management at the global level. SFM is supported by policies and legislation in $97 \%$ of forest areas worldwide, and the highest values are found in South and East Asia and Central and South America, with between 93\% and $100 \%$ [1]. Two of the main tools used to incentivize SFMs are stakeholder involvement and forest management plans. However, the percentage of forest areas with forest management plans varies by region, ranging from below $20 \%$ in South America and West and Central Africa to over $90 \%$ in Europe and Central America [1].

In this context, as a country participating in the workgroup on criteria and indicators for the Conservation and Sustainable Management of Temperate and Boreal Forests (Montreal Process), Chile has carried out a line of work aimed at developing support tools for the monitoring and assessment of the sustainability of forest management in subnational projects, conducting studies in areas with humid climates and mild summers in the regions of Araucania, Los Lagos, and Biobio (see Figure 1). 


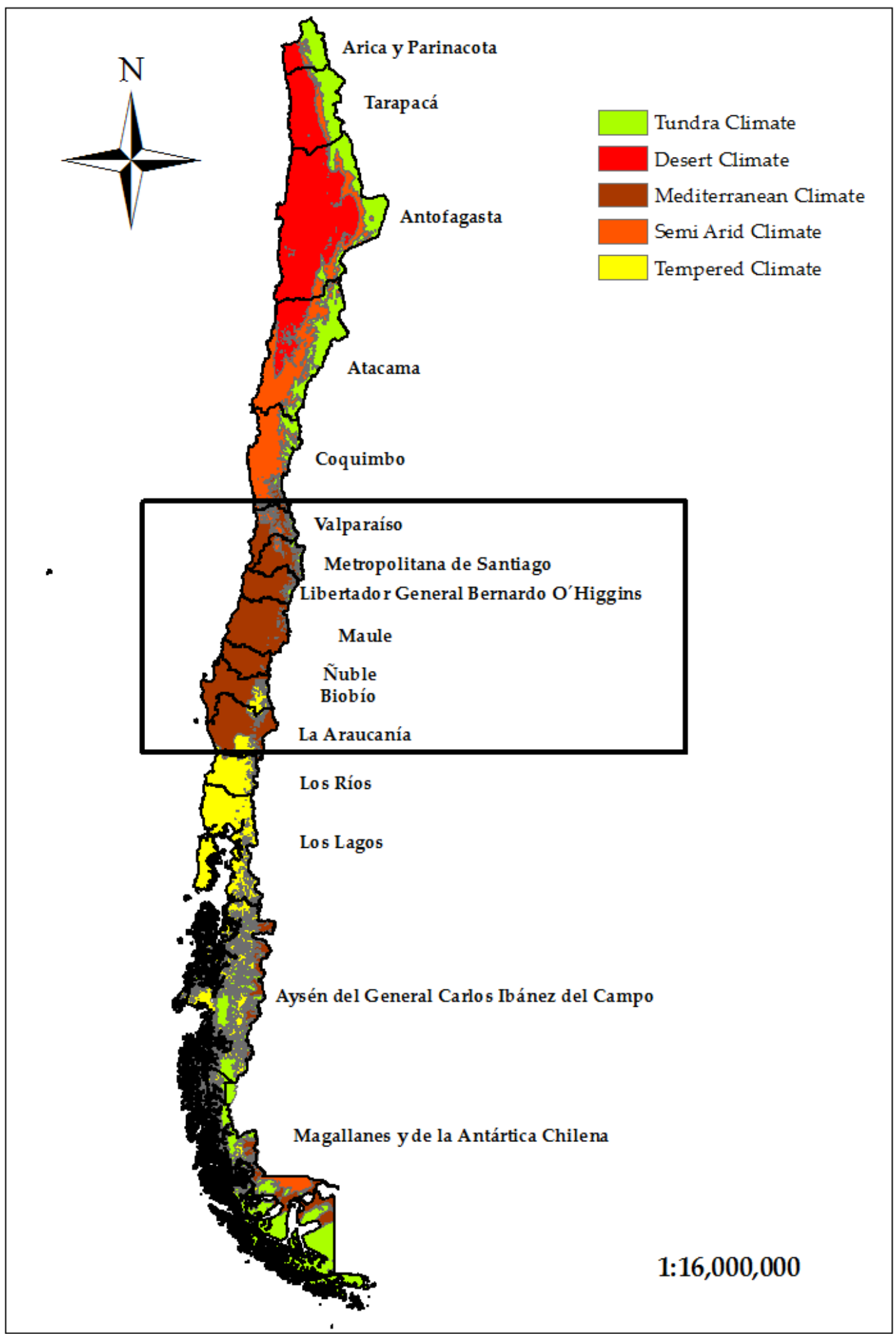

Figure 1. Climate types in the regions in Chile; the Mediterranean climate area is framed.

However, this line of work has not been applied to sclerophyllous forests, which today are far from their climax [2] in spite of being located in Chile's central region-the most developed and densely populated in the country-on the slopes of the Coastal Range and Los Andes and representing one of the world's diversity hotspots [3]. These forests are the most vulnerable to climate change, which increases their risk of land degradation and desertification [4]. According to the latest climate model 
simulations at the global level, global warming could increase dryland ecosystems from $11 \%$ to $23 \%$ of Earth's land surface by the end of the 21st century [4,5]. Although Chile has improved its subsidy requirements to favor SFLs, the lack of forest management plans in this region means that SFLs do not receive subsidies that could encourage landowners [6].

To protect the remaining native vegetation and possibly reverse its declining trend, it is essential to implement programs for sustainable management with the participation of the state and the private sector.

The VI Libertador General Bernardo O'Higgins Region is part of the central zone of Chile and is characterized by having extensive areas of this forest type, and by the fact that a large proportion of the forests are in the hands of small forest landowners [7]. The total area of native forests is 485,790 ha- 49,742 ha belong to 2957 SFLs, 413,126 ha to other private landowners, and 22,922 ha to protected areas, according to the 2013 Agroforestry Census developed by Instituto de Desarrollo Agropecuario de Chile. The application of the forest legislation may change these figures, but there is still no updated census.

The native forests in the possession of small forest landowners (SFL) are associated to other productive systems, such as agriculture and livestock farming, generating a wide variety of production units in the region. One characteristic of these subsystems is their low yields, mainly used for self-consumption, while any surplus goes for sale or exchange in order to ensure the subsistence and food security of the family group $[8,9]$.

Forest areas are mainly managed by their owners using their empirical skills and knowledge of the resource. However, these interventions have not been sufficient to maintain the productivity of the native forest [2]. In addition, activities such as changes in land use for agricultural purposes, the utilization of the native forest as a source of refuge and food for cattle, and the constant extraction of forest products without any sustainable management have contributed to reducing the tree cover and generated processes of forest fragmentation $[8,9]$.

Elsewhere, the successful implementation of sustainable actions requires both the local communities and the decision-makers to understand the ecological, environmental, and cultural dynamics and the productive potential of the forests [10].

Small forest landowners are a group with diverse social, economic, and productive characteristics. The lack of information on this population sector hinders the processes of decision making and the orientation of promotional instruments and support programs [8]. Their correct characterization can contribute to the design of forestry, agricultural, and livestock policies that facilitate the transfer of technology [11] and the development, implementation, and monitoring of rural development projects [12].

Classification is an important tool for reducing heterogeneity and complexity in planning. According to Carmona and Nahuelhual (2009) [13], "A typology is a way of conceptualizing this reality and allows the resources to be directed more effectively and efficiently. As a result, units of relation can be formed between decision-makers and their natural environment. It facilitates the spatial-temporal observation of the effects of their decisions at the level of the landscape and territory, and the results can be used to supplement future interventions according to the characteristics of the actors existing in it."

Previous work on the classification of rural family units and their associated property systems can be found in the literature. However, this classification has been done based on objective information and assessments, so the studies tend to be descriptive rather than explanatory or predictive [14,15].

Multivariate analysis methods offer objective classification techniques such as principal components analysis, multiple correspondence analysis and cluster analysis, which can group together the landowners with homogeneous characteristics in order to enable decisions to be made in a relatively similar way to allow the visualization, analysis, and understanding of the current productive systems so they can be given similar recommendations $[12,13,16]$. These techniques can be complemented with 
local expert knowledge [16] to identify sustainable lines of work as a basis for improving the focus of programs that promote scale economies and regional development [17].

The aim of this study is to characterize and typify small forest landowners in the Libertador General Bernardo O'Higgins Region using objective information and the participation of the local population, in addition to multivariate statistical techniques to identify problems and deficiencies and propose future lines of work that lead to the sustainable management of the territory and to rural development.

\section{Materials and Methods}

\subsection{Study Area}

The study area (see Figure 2) is located in the VI Libertador General Bernardo O'Higgins Region, Chile, between $33^{\circ} 51^{\prime} 02^{\prime \prime}$ and $34^{\circ} 56^{\prime} 36^{\prime \prime} \mathrm{S}$, and between $72^{\circ} 00^{\prime} 12^{\prime \prime}$ and $69^{\circ} 48^{\prime} 38^{\prime \prime}$ W. It has an area of $16,387 \mathrm{~km}^{2}$, and a population of 914,555 in 2017 [18]. The average altitude is $251 \mathrm{~m}$ a. s. 1 . from sea level to an altitude of $4500 \mathrm{~m}$. The local relief is divided into four characteristic sectors-the Los Andes Range, the intermediate depression, the Coastal Range, and the coastal plain. It has a predominantly Mediterranean climate characterized by rainy winters and dry summers. Average annual precipitation is $680 \mathrm{~mm}$, with variations caused by the local topography. The climate on the coast is cloudy with abundant humidity, whereas in the interior, there are significant temperature variations of over $13^{\circ} \mathrm{C}[19]$.

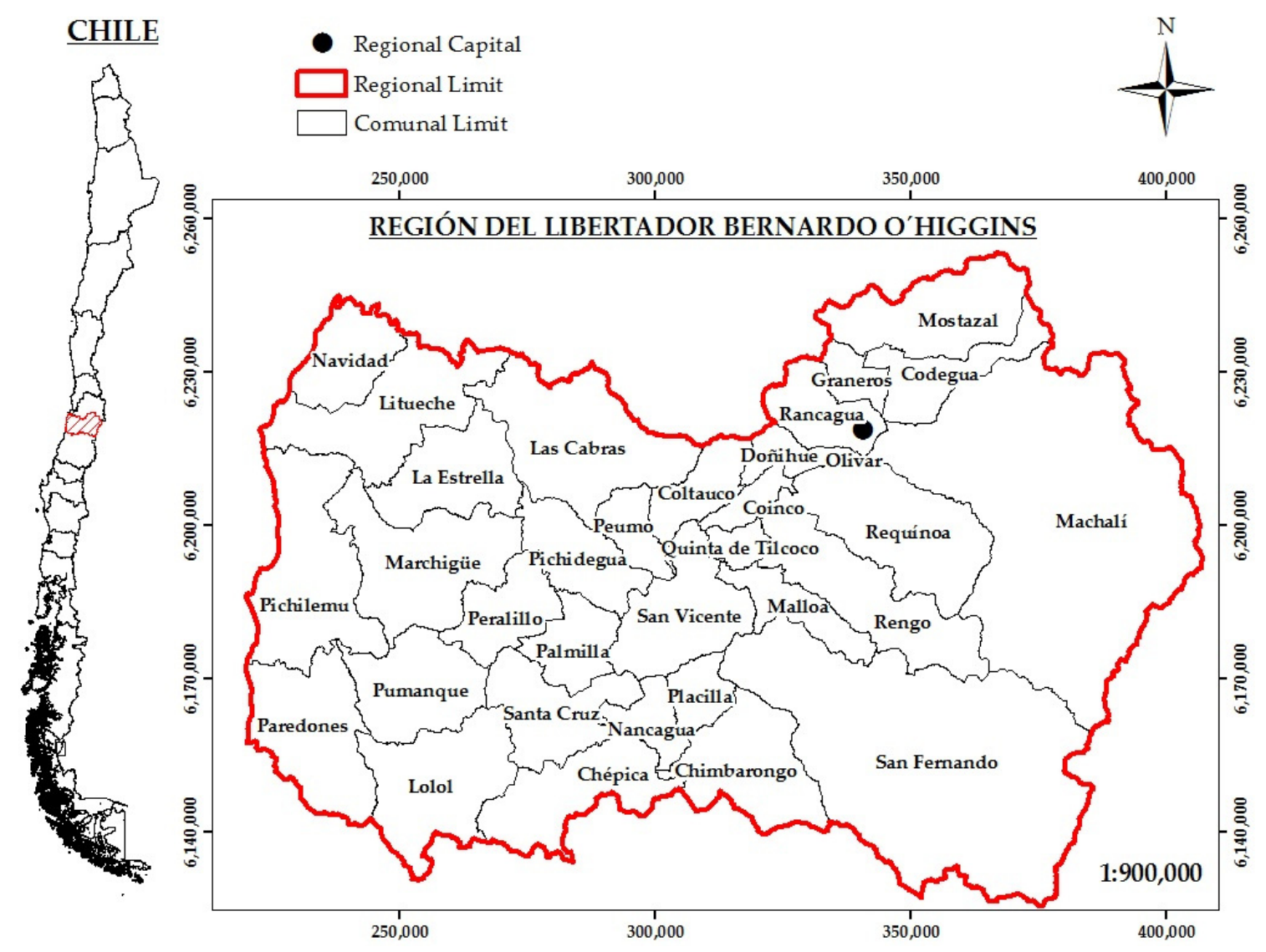

Figure 2. Map of the study area.

The plant diversity is high in terms of its composition, structure and conservation status. There is a predominance of tall shrubs with sclerophyllous leaves, along with low-growing xerophytic and spiny shrubs, succulents and very tall sclerophyllous, spiny laurifoliate trees. The dominant species include 
litre (Lithraea caustica (Molina) Hook et Arn), quillay (Quillaja saponaria Molina), peumo (Cryptocarya alba (Molina) Looser), boldo (Peumus boldus Molina), and espino (Acacia caven Molina) [19].

\subsection{Data Collection}

This analysis was begun by consulting the Native Forest Registry, which provided information on the forest type and the dominant species present in the study area. It should be noted that the map scale contemplated in the databases was in many cases insufficient, so this information was supplemented with validation campaigns on the terrain in the region that currently has native forest.

From the information available in the registry, an analysis was made of the communities in 2015, including the commune and property limits, toponymy, paths and population centers. The properties that complied with the restrictions imposed by Law 20.283 on the Recovery of the Native Forest and Forest Development in Chile were identified in each community. This document defines the characteristics of the SFLs as follows:

"A person who has the title deed for one or more rural properties with the presence of native forest, with a combined area of no more than 200 ha; whose assets do not exceed the equivalent of 3500 development units (accounting unit used in Chile to re-value savings in line with inflation rates so the money maintains its purchasing power); equivalent to 122,500 euros, whose income derives mainly from agricultural or forestry activities and who works directly on the land, on their property or on another property belonging to third parties."

This information was supplied by the following territorial institutions: National Forestry Corporation (CONAF), a local development program (PRODESAL), and municipalities in the region, who together directed the subsequent campaigns on the terrain for the survey of socio-economic information by first visualizing the spatial distribution of the small forest landowners in the region.

This information was used to prepare a census and a basic map to incorporate and analyze the properties and check whether they meet the legal requirement. There is currently no census of small forest landowners in Chile, as prescribed by this law.

The properties that met the requirements of this study were localized through campaigns on the terrain, involving visits to all the small landowners and their properties. Productive, social, and economic information was collected on the small forest landowners in the region. All the interviews were conducted with the head of the household.

Semi-structured interviews were carried out to capture primary information, on the form included in Appendix A. This procedure was chosen due to the open character of this kind of survey and the fact that they allow information to be obtained from the interviewee in a fluid way [20].

Finally, the information was incorporated into a database for its subsequent statistical analysis.

\subsection{Statistical Analysis}

The semi-structured interview provided information on 41 variables, from which were selected the most representative variables in the study. The data processing was done with IBM SPSS Statistics software version 20 (Armonk, NY, USA).

The variables were chosen according to the value of the coefficients of variation $(\mathrm{CV})$ for each initial variable, selecting the variables whose $\mathrm{CV}$ was greater than or equal to $50 \%$ of variability in terms of the mean [21].

The multivariant method of multiple correspondence analysis (MCA) was applied to the selected variables. This method analyzes the relation between categories of quantitative variables so their dimension can be reduced. Finally, Ward's method of hierarchical cluster analysis was applied to define homogeneous groups of SFLs in the study area according to their similarities for the variables ultimately selected [22]. 


\subsection{Validation of Typologies and Work Lines}

This study was conducted within the framework of the project "Program for training and technological transfer for a better application of Law 20.283, aimed at small landowners in the VI Region." In this project, the problems, needs, and training of the local communities were discussed with local leaders, and the SFL typologies were obtained. However, forest activities were proposed to each landowner according to the characteristics of the property and in compliance with Law 20.283.

In addition, each typology was validated and the landowners' problems and future lines of work were identified by consulting a panel of experts described in Table 1.

Table 1. Experts consulted for the validation of typologies and lines of work proposed.

\begin{tabular}{cc}
\hline \multicolumn{1}{c}{ Specialty } & Institution \\
\hline Forestry Engineer; Diploma of Specialization in Silviculture & University of Chile \\
\hline Forestry Engineer; Doctor in Forestry Science & University of Chile \\
\hline Veterinarian; Doctorate in Agrarian Economy & University of Chile \\
\hline $\begin{array}{c}\text { Veterinarian; Technical head of PRODESAL; Specialist in } \\
\text { rural development }\end{array}$ & Local development program, Lolol \\
\hline $\begin{array}{c}\text { Agricultural technician; Technician PRODESAL; Specialist in } \\
\text { rural development }\end{array}$ & Local development program, Chépica \\
\hline Forestry Engineer; Head of Forestry Department & National Forestry Corporation \\
\hline Forestry Engineer; Forest Extension Specialist & National Forestry Corporation \\
\hline
\end{tabular}

\section{Results and Discussion}

\subsection{Spatial Distribution of Small Forest Landowners in the Region}

The analysis of the maps, supplemented with information from territorial institutions, initially identified 420 small forest landowners in the region, which represented $14 \%$ of the total SFLs, according to the 2013 Agroforestry Census. The 420 small forest landowners were natural persons and not companies or associations. In the interview it was verified that the property met the requirements established by Law 20.283 in its definition of the characteristics of the small forest landowner. This verification eliminated any landowner who did not fulfill any of the following requirements: the property did not have native forest, the area was larger than 200 ha, the landowners did not have the deed to the property, or the information collected in the survey was incomplete. Finally, the number of SFLs was reduced to 211. Average area of native forest in this sample was $18.25 \mathrm{ha}$, and the sampling relative error was $16 \%$.

A useful map was generated for the subsequent classification of the producers based on the number of properties that meet the initial criteria for selection and analysis for each commune.

Table 2 shows the community to which the SFLs belong, the associated area of native forest and the number of landowners. Figure 3 shows their location. As can be seen in Figure 3, no landowners can be seen in the eastern and western zone (Coastal Range and Los Andes Range) of the map as the forests in these zones are not sclerophyllous. 
Table 2. Spatial distribution of small forest landowners and area of native forest at the commune level.

\begin{tabular}{cccccc}
\hline Commune & $\begin{array}{c}\text { Number of } \\
\text { SFLs }\end{array}$ & $\begin{array}{c}\text { Area of } \\
\text { Native Forest } \\
\text { (ha) }\end{array}$ & Commune & $\begin{array}{c}\text { Number of } \\
\text { SFLs }\end{array}$ & $\begin{array}{c}\text { Area of } \\
\text { Native Forest } \\
\text { (ha) }\end{array}$ \\
\hline Chépica & 37 & 545.3 & Nancagua & 5 & 207 \\
Coinco & 1 & 8 & Navidad & 6 & 41.5 \\
Coltauco & 7 & 114.8 & Palmilla & 5 & 34.5 \\
Doñihue & 12 & 260.3 & Peralillo & 12 & 119.3 \\
La Estrella & 9 & 238 & Pichidegua & 11 & 203 \\
Las Cabras & 2 & 61 & Placilla & 8 & 211.3 \\
Litueche & 14 & 135.3 & Pumanque & 15 & 403.25 \\
Lolol & 28 & 702 & Quinta de Tilcoco & 1 & 10 \\
Machalí & 4 & 48.1 & Requínoa & 1 & 0.5 \\
Malloa & 6 & 61.8 & San Vicente & 8 & 79.5 \\
Marchigüe & 11 & 260 & Santa Cruz & 9 & 293.36 \\
Total SFLs & & 211 & Total area & & 4035.81 \\
\hline
\end{tabular}

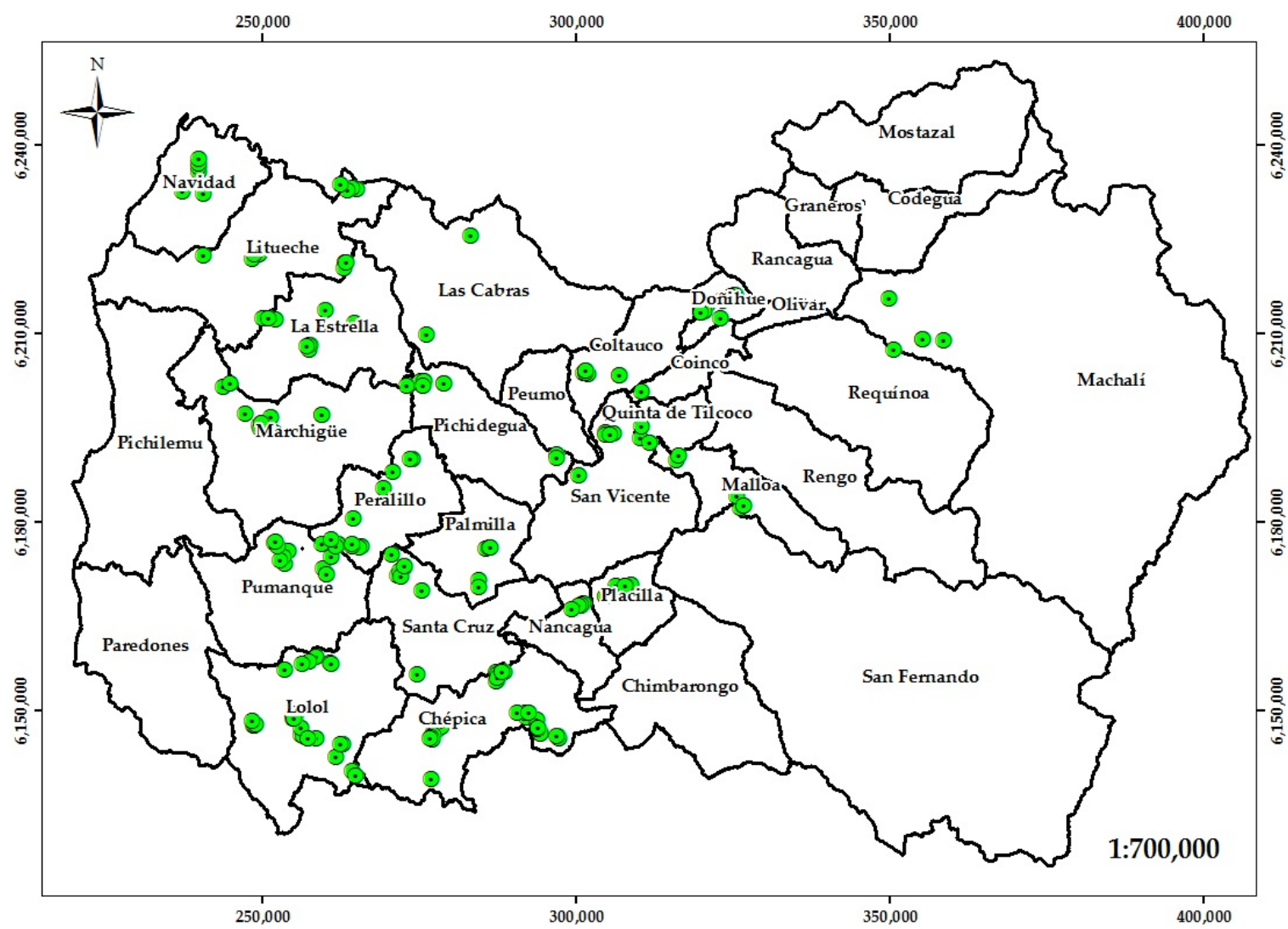

Figure 3. Spatial distribution of small forest landowners (SFL) in the Libertador General Bernardo O’Higgins Region.

\subsection{Identification of Landowner Groups}

\subsubsection{Initial Variables}

The choice of variables was made according to their discriminant power, based on their coefficient of variation and prior studies. Of the total of 14 variables selected, four correspond to quantitative variables and ten to categorical variables. The selected quantitative variables were age of the head of household (AG), property area (PA), area of native forest (NFA), and per capita income (PCI). The selected qualitative variables were type of animal unit (AU), economic activity of the head of household (EA), forest status (FS), education of the head of household (ED), infrastructure (IN), 
extraction of forest products (FP), main problem (MP), main productive subsystem (MPS), training subject (TR), and source of water for agriculture and livestock (WS).

\subsubsection{Results of the Multiple Correspondence Analysis}

The multiple correspondence analysis separated three dimensions that explain $60 \%$ of the total variance, each with similar inertia values of between $18.4 \%$ and $21.3 \%$.

Table 3 shows the discriminatory capacity of each variable in each dimension. As can be seen, Dimension 1 is mainly explained by productive variables (main productive subsystem, type of animal unit, and source of water for agriculture and livestock); Dimension 2 is explained by property variables (property area and area of native forest); and Dimension 3 is explained by social variables (age, main economic activity, and education of the head of household).

Table 3. Discriminant measures for each variable.

\begin{tabular}{|c|c|c|c|c|c|c|c|c|c|}
\hline \multirow{2}{*}{ Variable } & \multicolumn{3}{|c|}{ Dimension } & \multirow{2}{*}{ Mean } & \multirow{2}{*}{ Variable } & \multicolumn{3}{|c|}{ Dimension } & \multirow{2}{*}{ Mean } \\
\hline & 1 & 2 & 3 & & & 1 & 2 & 3 & \\
\hline AG & 0.257 & 0.145 & 0.416 & 0.273 & $\mathrm{AU}$ & 0.375 & 0.249 & 0.049 & 0.224 \\
\hline EA & 0.320 & 0.230 & 0.363 & 0.304 & FS & 0.106 & 0.024 & 0.056 & 0.062 \\
\hline ED & 0.187 & 0.204 & 0.260 & 0.217 & IN & 0.181 & 0.190 & 0.086 & 0.152 \\
\hline PA & 0.211 & 0.431 & 0.240 & 0.294 & $\mathrm{FP}$ & 0.062 & 0.132 & 0.010 & 0.068 \\
\hline NFA & 0.153 & 0.364 & 0.267 & 0.261 & $\mathrm{MP}$ & 0.145 & 0.085 & 0.145 & 0.125 \\
\hline MPS & 0.477 & 0.273 & 0.155 & 0.302 & $\mathrm{TR}$ & 0.208 & 0.187 & 0.244 & 0.213 \\
\hline WS & 0.268 & 0.183 & 0.185 & 0.212 & PCI & 0.320 & 0.230 & 0.363 & 0.304 \\
\hline
\end{tabular}

\subsubsection{Grouping of Landowners}

The cluster analysis, through Ward's method, identified small landowners with similar characteristics in the three dimensions (eight variables) obtained from the MCA-property, productive, and social. Based on this, four homogeneous groups of producers were formed: elderly SFLs, retired SFLs, largest SFLs, and middle-aged SFLs, as shown in Table 4.

Table 4. Description of typologies based on variables obtained from the multiple correspondence analysis (MCA).

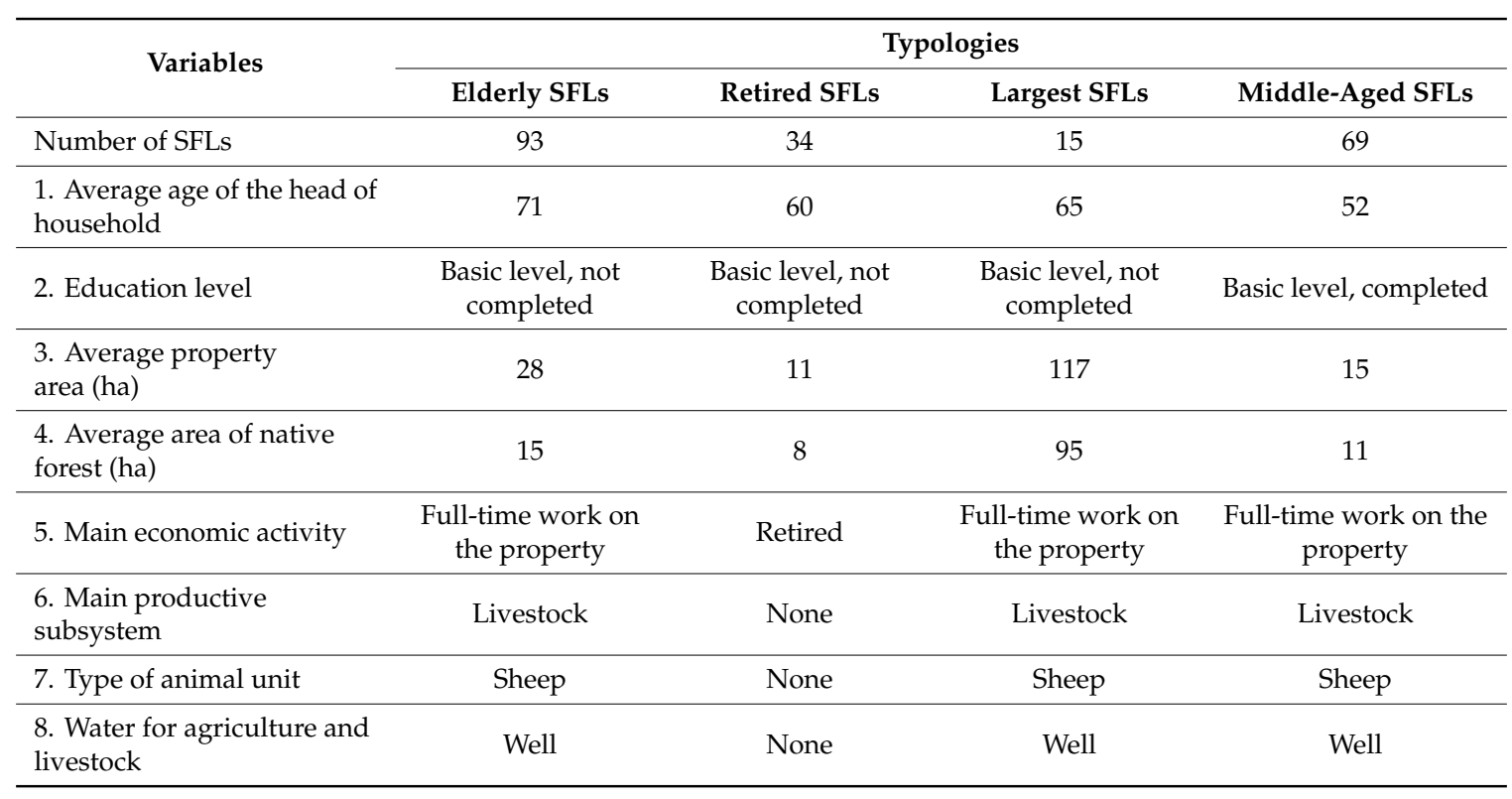


The reduction of the sample size from 420 SFL to 211 implied a smaller sample size for each typology and a greater sampling error. The highest standard deviation (SD) for the different variables and typologies in Table 6 corresponded to largest SFLs, with 15\%, while the maximum SD for the other typologies was $5 \%$ for the elderly SFLs, $8.5 \%$ for retired SFLs, and $9.2 \%$ for middle-aged SFLs. In further studies, it will be necessary to increase the sample size of the SFL with the largest properties.

The characterization of producers was supplemented with information on specific variables related to forest management, agricultural production, and characteristics of the family groups obtained in the survey in order to refine the profile of each type of producer and observe some of the typical problems in each group (see Tables 5 and 6).

Table 5. Characteristics of the family group.

\begin{tabular}{|c|c|}
\hline Typology & Family Members and Activities \\
\hline Elderly SFLs & $\begin{array}{c}52 \%, 1 \text { or } 2 \text { members: activities related to the property. } \\
48 \% \text {, over } 2 \text { members: } 23 \% \text { students; } 13 \% \text { engaged in activities related to the property; } 64 \% \\
\text { other activities }\end{array}$ \\
\hline Retired SFLs & $\begin{array}{c}56 \%, 1 \text { or } 2 \text { members: retired. } \\
\begin{array}{c}44 \% \text {, over } 2 \text { members: } 23 \% \text { students; } 6 \% \text { engaged in activities related to the property; } 23 \% \\
\text { other full-time activities }\end{array}\end{array}$ \\
\hline Largest SFLs & $\begin{array}{l}66 \%, 1 \text { or } 2 \text { members: activities related to the property } \\
34 \% \text {, over } 2 \text { members: } 100 \% \text { engaged in activities related to the property; }\end{array}$ \\
\hline Middle-aged SFLs & $\begin{array}{l}39 \%, 1 \text { or } 2 \text { members: activities related to the property. } \\
61 \% \text {, over } 2 \text { members: } 25 \% \text { students, } 16 \% \text { engaged in activities related to the property. }\end{array}$ \\
\hline
\end{tabular}

Table 6. General observations for each typology.

\begin{tabular}{|c|c|c|c|c|}
\hline \multirow{2}{*}{ Variables } & \multicolumn{4}{|c|}{ Typology } \\
\hline & Elderly SFLs & Retired SFLs & Largest SFLs & Middle-Aged SFLs \\
\hline $\begin{array}{l}\text { SFLs who extract forest } \\
\text { products: \%/no./SD }\end{array}$ & $63 / 59 / 0.05$ & $44 / 22 / 0.085$ & $73 / 11 / 0.11$ & $50 / 35 / 0.06$ \\
\hline Main species & Acacia caven & $\begin{array}{l}\text { Acacia caven and } \\
\text { Peumus boldus }\end{array}$ & $\begin{array}{l}\text { Acacia caven and } \\
\text { Peumus boldus }\end{array}$ & Acacia caven \\
\hline Main product extracted & Firewood & Firewood & $\begin{array}{l}\text { Firewood, charcoal, } \\
\text { boldo leaves }\end{array}$ & Firewood \\
\hline $\begin{array}{l}\text { Destination of the } \\
\text { production }\end{array}$ & Self consumption & Self consumption & $\begin{array}{l}\text { Self consumption and } \\
\text { commercialization }\end{array}$ & Self consumption \\
\hline Forestry management plan & No & No & No & No \\
\hline Forest structure & $\begin{array}{l}\text { Mature with scarce } \\
\text { regeneration }\end{array}$ & $\begin{array}{l}\text { Mature with scarce } \\
\text { regeneration }\end{array}$ & $\begin{array}{l}\text { Mature with scarce } \\
\text { regeneration }\end{array}$ & $\begin{array}{l}\text { Mature with scarce } \\
\text { regeneration }\end{array}$ \\
\hline Forest status & $\begin{array}{l}\text { Highly intervened } \\
\text { Intense soil erosion }\end{array}$ & $\begin{array}{l}\text { Minimally } \\
\text { intervened, low } \\
\text { soil erosion }\end{array}$ & $\begin{array}{l}\text { Highly intervened in } \\
\text { some sectors }\end{array}$ & $\begin{array}{l}\text { Highly intervened in } \\
\text { some sectors }\end{array}$ \\
\hline $\begin{array}{l}\text { Forest activity performed } \\
\text { by SFLs }\end{array}$ & Clearing & Clearing & Nothing & Clearing \\
\hline Agricultural production & Private orchard & Private orchard & Private orchard & Private orchard \\
\hline Equipment & Animal traction & Nothing & $\begin{array}{l}\text { Mechanically } \\
\text { powered }\end{array}$ & Animal traction \\
\hline $\begin{array}{l}\text { Destination of the } \\
\text { production }\end{array}$ & Self consumption & Self consumption & Self consumption & Self consumption \\
\hline $\begin{array}{l}\text { Minimum distance to } \\
\text { paved road }\end{array}$ & $10 \mathrm{~km}$ & $10 \mathrm{~km}$ & $10 \mathrm{~km}$ & $10 \mathrm{~km}$ \\
\hline Problems & $\begin{array}{l}\text { Availability of } \\
\text { water }\end{array}$ & $\begin{array}{c}\text { Availability of } \\
\text { water Connectivity }\end{array}$ & $\begin{array}{l}\text { Availability of water } \\
\text { Basic services }\end{array}$ & Availability of water \\
\hline $\begin{array}{l}\text { SFLs with training: } \\
\% / \text { no./SD }\end{array}$ & $66 / 61 / 0.05$ & $34 / 12 / 0.08$ & $60 / 9 / 0.15$ & $44 / 30 / 0.06$ \\
\hline
\end{tabular}


Table 6. Cont.

\begin{tabular}{|c|c|c|c|c|}
\hline \multirow{2}{*}{ Variables } & \multicolumn{4}{|c|}{ Typology } \\
\hline & Elderly SFLs & Retired SFLs & Largest SFLs & Middle-Aged SFLs \\
\hline $\begin{array}{l}\text { SFLs trained in the subject } \\
\text { of forestry: \%/no./SD }\end{array}$ & $6 / 6 / 0.024$ & $18 / 6 / 0.07$ & $30 / 5 / 0.12$ & $15 / 10 / 0.09$ \\
\hline $\begin{array}{l}\text { SFLs participating in social } \\
\text { organizations: \%/no./SD }\end{array}$ & $83 / 77 / 0.04$ & $61 / 21 / 0.08$ & $73 / 11 / 0.12$ & $73 / 50 / 0.05$ \\
\hline Social organization & $\begin{array}{l}\text { Neighborhood } \\
\text { association }\end{array}$ & $\begin{array}{l}\text { Neighborhood } \\
\text { association }\end{array}$ & $\begin{array}{l}\text { Neighborhood } \\
\text { association }\end{array}$ & $\begin{array}{l}\text { Neighborhood } \\
\text { association }\end{array}$ \\
\hline $\begin{array}{l}\text { Properties entered in the } \\
\text { property register: } \\
\% / \text { no./SD }\end{array}$ & $71 / 66 / 0.047$ & $56 / 19 / 0.08$ & $67 / 10 / 0.14$ & $62 / 43 / 0.06$ \\
\hline Employees & 0 & 0 & 0 & 0 \\
\hline Per capita income & $\$ 8-\$ 150$ & $\$ 8-\$ 150$ & $\$ 238-\$ 426$ & $\$ 8-\$ 150$ \\
\hline
\end{tabular}

By typifying the small forest landowners in the region, it was possible to recognize their characteristics and the problems that need to be tackled in a specific way for each situation. This diagnostic is essential for designing programs or lines of work. The detailed analysis of the variables revealed the similarities and differences between the four typologies of small forest landowners in the Libertador General Bernardo O'Higgins Region.

Similar behavior was observed in the characteristics of the head of household, namely advanced average age and low education level. Most landowners in the typologies elderly SFLs, retired SFLs, and largest SFLs are illiterate. Middle-aged SFLs, the youngest group (average 52 years), have completed at least the basic education level, and $63 \%$ of the university graduates interviewed belong to this group.

The main economic activity among elderly SFLs and largest SFLs is full-time work on the property, and the livestock subsystem accounts for the largest proportion of household income. This is followed by the agricultural subsystem, whose yield is used for the consumption of the family group. In the case of the retired SFLs, the producers' income comes mainly from their retirement, and although the main economic activity in the middle-aged SFLs typology is full-time work on the property $(41 \%), 39 \%$ of the producers carry out activities outside the property on either a full-time or seasonal basis. They are also quite isolated. The closest paved road is at least $10 \mathrm{~km}$ away, which hinders their access to markets and services.

The size of the property is the main difference between typologies from the economic point of view. SFLs in the largest SFLs typology have the largest properties (117 ha) on average, with an average of 93 ha of native forest. The largest SFLs typology has the lowest number of SFLs, with 15 out of a total of 221, indicating the dispersion of properties in the native forest, which is a disadvantage for forest management.

This is the only group that rents mechanical traction equipment; it also has the highest per capita income, at between $\$ 238$ and $\$ 426$, and the highest number of owners who extract forest products, including firewood, charcoal, and boldo leaves. These are the only producers who allocate part of the products extracted from the forest for commercialization, and 50\% have received training in the field of forestry, although the total number of trained people is close to the other typologies. This typology has the highest number of family members involved in the management of the property, which ensures their future engagement with forest management and production. However, there are no data on the volume of the products extracted for any of the typologies. Firewood is used as a source of energy for the home and for cooking, which explains the interest among the SFLs in the restoration of native forests, as this would represent a source of savings [9,23,24].

Regarding the status and management of the native forest, the landowners have very little training in forest management, with only 27 SFLs trained in the subject of forestry. The largest SFLs typology, with the highest average size, has the highest proportion and the best forest training. The only forest 
activity the landowners perform is clearing. According to the answers in the survey, they consider this activity to be the correct way to manage the forest. This lack of knowledge of forest management, coupled with the fact that none of the native forest properties had a forestry plan, leads to a substantial rate of intervention in the forest, which causes little regeneration and soil erosion problems. In addition, since property passes down through families, many new landowners are not entered in the property registry. This is one of the main problems when applying for subsidies and reduces the capacity for production, forest conservation, and water management [8,9]. These problems also have a global impact, as these landowners play an important role in preventing the deforestation of the native forest, which has great potential for carbon mitigation [25].

In this context, there is a unanimous need for all the typologies to implement sustainable management plans whose activities could be subsidized (Law 20.283 on the Recovery of the Native Forest and Forest Development), and for training in forest management, the role of the native forest, and the market for and commercialization of timber and non-timber forest products.

This would represent a first step toward the recovery of these forests, increase water availability, and encourage forest development among landowners [6]. The activities identified according to the landowners' typology and the use of the forest, validated by the panel of experts, are shown in Table 7 .

Table 7. Eligible activities proposed by typology.

\begin{tabular}{|c|c|c|c|c|}
\hline & \multicolumn{4}{|c|}{ Typology } \\
\hline & Elderly SFLs & Retired SFLs & Largest SFLs & Middle-Aged SFLs \\
\hline Objective & Timber production & Timber production & Timber production & Timber production \\
\hline Main species & Acacia caven & $\begin{array}{c}\text { Acacia caven and } \\
\text { Peumus boldus }\end{array}$ & $\begin{array}{l}\text { Acacia caven and } \\
\text { Peumus boldus }\end{array}$ & Acacia caven \\
\hline Activities & $\begin{array}{c}\text {-Cleaning, pruning, } \\
\text { thinning } \\
\text {-Supplementary } \\
\text { planting }\end{array}$ & $\begin{array}{c}\text {-Regenerative felling } \\
\text {-Natural regeneration } \\
\text {-Cleaning, pruning, } \\
\text { thinning }\end{array}$ & $\begin{array}{c}\text {-Cleaning, pruning, } \\
\text { thinning } \\
\text {-Supplementary planting } \\
\text {-Infiltration ditches } \\
\text {-Protection against } \\
\text { forest fires }\end{array}$ & $\begin{array}{c}\text {-Cleaning, pruning } \\
\text { thinning } \\
\text {-Supplementary } \\
\text { planting }\end{array}$ \\
\hline
\end{tabular}

The SFLs' only type of organization is the neighborhood association to which they belong. There is no kind of SFL community forest management in the region that promotes the conservation of forests, ensures the landowners' income from the use of the forest, and improves the governance of the management $[26,27]$.

There is therefore a lack of resources to transform these SFLs into the main agents of their development, intervening in the decision-making processes together with other stakeholders (technicians, administration, policy-makers), and avoiding the generation of policies at the territorial level that have a generalizing tendency and whose impact is unclear [23,28]. This would increase the efficiency of their own potential and of the public and private initiatives that affect their development $[9,28]$.

As a line of work for local management, we therefore propose the creation of social innovation and knowledge dissemination networks that make it possible to design, operate and assess strategies to stimulate innovation among the landowners. These networks are systems of informal interrelation that can be easily disassembled and recombined, encouraging non-hierarchical relations of trust between their members (SFLs, other landowners, technicians, Administration), and may endure over time [29]. In the case of the SFLs in the VI Region, after characterizing the landowners and identifying the forestry technology practices and innovations to be adopted, the key local actors can be identified due to their greater knowledge of the forestry activity or higher social prestige. These key local actors catalyze the processes of dissemination and adoption of innovations [30]. 


\section{Conclusions}

The main contribution of this article is to present for the first time a study on the characterization and the problems of small forest landowners of native sclerophyllous forests in the Libertador General Bernardo O'Higgins Region.

Sclerophyllous forests are extremely sensitive to global warming, and the sclerophyllous forest in the hands of small forest landowners in this region of Chile is degraded in spite of its high ecological value. Due to the total lack of forest management, the yield obtained from the native forests is very low.

Although the characterization of small forest landowners reveals clear differences in terms of the surface area of their properties, the vast majority have a similar social profile, a low education level, and very advanced ages. This information is important for devising the training strategy to be used. The main product extracted is firewood for self-consumption for the household, leading to various degrees of intervention in the resource.

This classification allowed the design of proposals for activities for sustainable management in the future, promoting regeneration either naturally or through planting, and fundamentally clearing and thinning activities, in order to reduce the continuous degradation of the native forest while considering the current legal aspects and the access to subsidies, all supported by specific forestry training plans for each typology.

It is therefore necessary to develop participative political processes that ensure rural development, the creation of associations of forest landowners, training, and the sustainable management of these forest areas. This should include the measurement of criteria and indicators in order to monitor their ecological, economic and social development, and the incentivization of research into areas of sclerophyllous forest.

Finally, the methodology presented in this study, with its quantitative focus, can be replicated in sectors where there is no information available on small forest landowners, in order to generate areas for recommendation that consider the needs of the local population and ensure they are not merely passive actors in their own development processes.

Author Contributions: Conceptualization, F.R.-G.; R.G.-S., and S.M.-F.; Data collection, F.R.-G. and R.G.-S. Formal analysis, F.R.-G. and S.M.-F.; Writing-Original draft, F.R.-G. and S.M.-F.; Writing-Review and editing, S.M.-F. and R.G.-S.

Funding: This research received no external funding.

Acknowledgments: We would like to thank the project "Program for training and technological transfer for a better application of Law 20.283, aimed at small landowners in the VI Region" financed by the Research Fund into the Native Forest at the National Forest Corporation and executed by the University of Chile.

Conflicts of Interest: The authors declare no conflict of interest.

\section{Appendix A}

Table A1. Interview applied to small forest landowners in the Libertador General Bernardo O'Higgins Region.

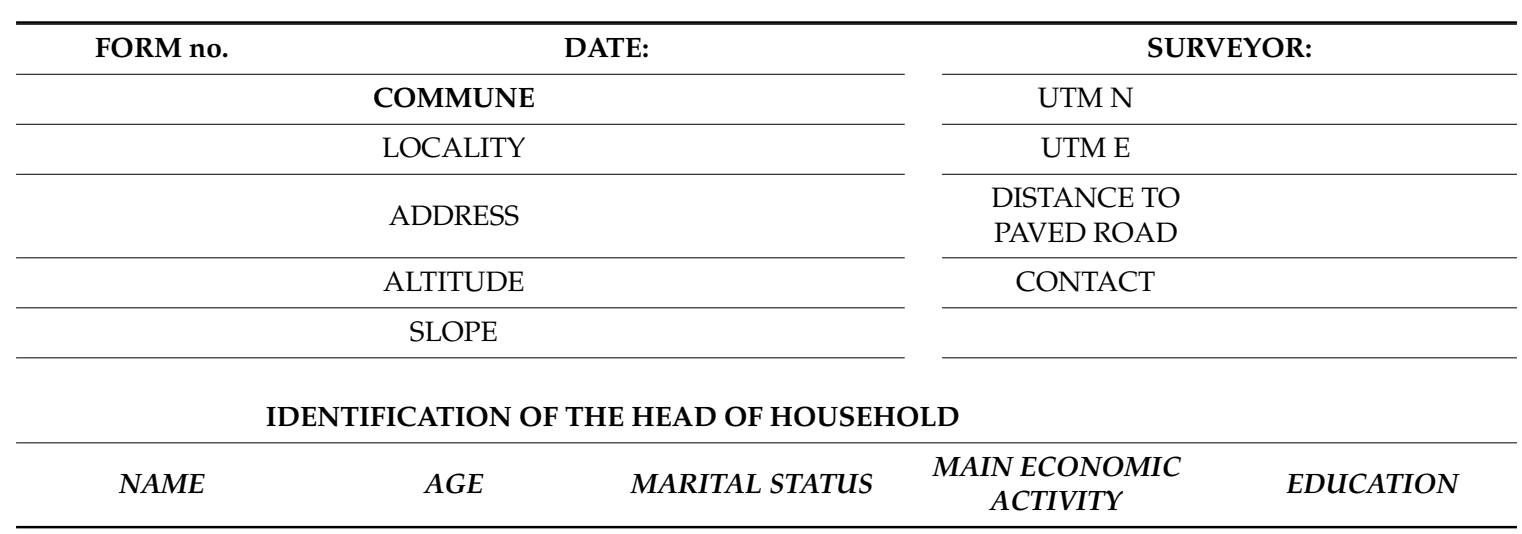


Table A1. Cont.

CHARACTERISTICS OF THE FAMILY GROUP

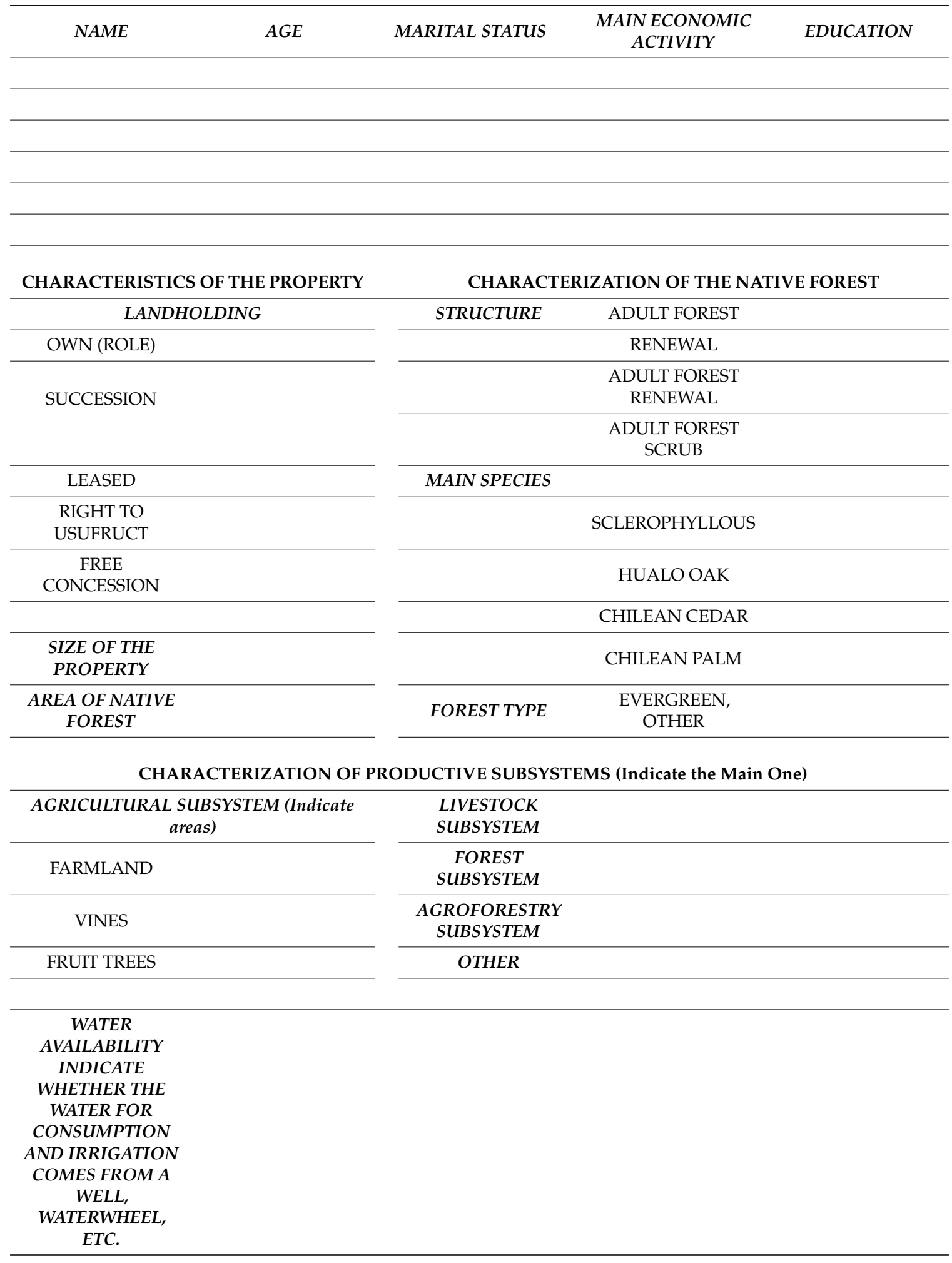


Table A1. Cont.

\begin{tabular}{l}
\hline YIELDS. \\
EXTRACTION OF \\
TIMBER AND \\
NON-TIMBER \\
FOREST \\
PRODUCTS. \\
INDICATE WHICH \\
ONES AND WHAT \\
QUANTITY \\
\hline NUMBER AND \\
TYPE OF ANIMAL \\
UNITS \\
\hline ANIMAL-DRAWN \\
AND \\
MECHANICAL \\
TRACTION \\
EQUIPMENT. \\
\hline GENERAL \\
INFRASTRUCTURE \\
(DESCRIBE) \\
\hline
\end{tabular}

\section{References}

1. MacDicken, K.G.; Sola, P.; Hall, J.E.; Sabogal, C.; Tadoum, M.; Wasseige, C. Global progress toward sustainable forest management. For. Ecol. Manag. 2015, 352, 47-56. [CrossRef]

2. Castillo, M.; Molina, J.R.; Rodríguez y Silva, F.; García-Chevesich, P.; Garfias, R. A system to evaluate fire impacts from simulated fire behavior in Mediterranean areas of Central Chile. Sci. Total Environ. 2016, 579, 1410-1418. [CrossRef] [PubMed]

3. Armesto, J.J.; Arroyo, M.; Hinojosa, L.F. The Mediterranean environment of Central Chile. In The Physical Geography of South America; Velben, T.T., Young, K.R., Orme, A.R., Eds.; Oxford University Press: New York, NY, USA, 2007; pp. 184-199.

4. Bastin, J.F.; Berrahmouni, N.; Grainger, A.; Maniatis, D.; Mollicone, D.; Moore, R.; Patriarca, C.; Picard, N.; Sparrow, B.; Abraham, E.M.; et al. The extent of forest in dryland biomes. Science 2017, 356, 635-638. [CrossRef]

5. Huang, J.; Yu, H.; Guan, X.; Wang, G.; Guo, R. Accelerated dryland expansion under climate change. Nat. Clim. Chang. 2016, 6, 166-171. [CrossRef]

6. Cubbage, F.; Harou, P.; Sills, E. Policy instruments to enhance multi-functional forest management. For. Policy Econ. 2007, 9, 833-851. [CrossRef]

7. Garfias, R.; Soto, M.C.; Gozalvo, F.R.; Alonso, A.V.; Intveen, H.B.; Cerrillo, R.N. Remants of schlerophyllous forest in the mediterranean zone of central Chile: Characterization and distribution of fragments. Interciencia 2018, 43, 655-663.

8. Bahamondez, A.; Rivas, E. Comunidades vinculadas a los Recursos Vegetacionales. In Bosque Nativo, Comunidades y Cambio Climático; Bahamondez, A., Ed.; European Union Commission: Brussels, Belgium, 2016; pp. 87-112.

9. FAO. State of the Forests in the World: Forest Pathways to Sustainable Development; Food and Agriculture Organization of United Nations: Roma, Italy, 2018; p. 153.

10. Estrada, C.; Irisity, F.; Hernández, G.; Torres, J. Casos Ejemplares de Manejo Forestal Sostenible en Chile, Costa Rica, Guatemala y Uruguay; Food and Agriculture Organization of United Nations: Roma, Italy, 2016; p. 236.

11. Aquino, V.; Camarena, F.; Julca, A.; Jiménez, J. Multivariate characterization of tarwi (Lupinus mutabilis Sweet) producing farms of the Mantaro Valley, Peru. Sci. Agropecu. 2018, 9, 269-279. [CrossRef] 
12. Kuivanen, K.; Álvarez, S.; Michalscheck, M.; Adjei-Nsiah, S.; Descheemaeker, K.; Mellon-Bedi, S.; Groot, J.C. Characterising the diversity of smallholder farming systems and their constraints and opportunities for innovation: A case study from the Northern Region, Ghana. NJAS Wagening. J. Life Sci. 2016, 78, 153-166. [CrossRef]

13. Carmona, A.; Nahuelhual, L. Tipificación y caracterización de sistemas prediales: Caso de estudio en Ancud, Isla de Chiloé. Classification and characterization of farming systems: Case study in the municipality of Ancud, Chiloé Island. Agro Sur 2009, 37, 189-199. [CrossRef]

14. González-Redondo, P.; Delgado-Pertíñez, M.; Toribio, S.; Ruiz, F.A.; Mena, Y.; Caravaca, F.P.; Castel, J.M. Characterisation and typification of the red-legged partridge (Alectoris rufa) game farms in Spain. Span. J. Agric. Res. 2013, 8, 624-633. [CrossRef]

15. Köbrich, C.; Rehman, T.; Khan, M. Typification of farming systems for constructing representative farm models: Two illustrations of the application of multi-variate analyses in Chile and Pakistan. Agric. Syst. 2003, 76, 141-157. [CrossRef]

16. Mądry, W.; Gozdowski, D.; Roszkowska-Mądra, B.; Castel, J.M.; Mena, Y.; Hryniewski, R. An overview of farming system typology methodologies and its use in the study of pasture-based farming system: A review. Span. J. Agric. Res. 2013, 11, 316-326. [CrossRef]

17. Carrillo Anzures, F.; Acosta Mireles, M.; Flores Ayala, E.; Torres Rojo, J.M.; Sangerman-Jarquín, D.M.; González, L.; Buendía, E. Caracterización de productores forestales en 12 estados de la República Mexicana. Rev. Mex. Cienc. Agric. 2017, 8, 1561-1573. [CrossRef]

18. Censo de Chile. 2017. Available online: http://www.censo2017.cl/ (accessed on 21 September 2019).

19. Región del Libertador Bernardo O’Higgins. Available online: https://www.bcn.cl/siit/nuestropais/region6/ (accessed on 20 June 2019).

20. Vega, N. La Entrevista Como Fuente De Información: Orientaciones Para Su Utilización. In Memoria e Historia del Pasado Reciente. Problemas Didácticos y Disciplinares; Alonso, L., Falchini, A., Eds.; Secretaría de Extensión, Universidad Nacional del Litoral: Santa Fe, Argentina, 2009; pp. 51-77.

21. Wei, X.; Allen, N.J.; Liu, Y. Disparity in organizational research: How should we measure it? Behav. Res. Methods 2016, 48, 72-90. [CrossRef] [PubMed]

22. Martín-Fernández, S.; Martinez-Falero, E. Sustainability assessment in forest management based on individual preferences. J. Environ. Manag. 2018, 206, 482-489. [CrossRef] [PubMed]

23. Herrmann, T.M.; Torri, M.C. Changing forest conservation and management paradigms: Traditional ecological knowledge systems and sustainable forestry: Perspectives from Chile and India. Int. J. Sustain. Dev. World Ecol. 2009, 16, 392-403. [CrossRef]

24. Li, Y.; Mei, B.; Linhares-Juvenal, T. The economic contribution of the world's forest sector. For. Policy Econ. 2019, 100, 236-253. [CrossRef]

25. Watson, R.T.; Noble, I.R.; Bolin, B.; Ravindranath, N.H.; Verardo, D.J.; Dokken, D.J. Land Use, Land-Use Change, and Forestry, Intergovernmental Panel on Climate Change (IPCC) 2000; Cambridge University Press: New York, NY, USA, 2000; p. 388.

26. Agrawal, A.; Chhatre, A.; Hardin, R. Changing governance of the world's forests. Science 2008, 320, 1460-1462. [CrossRef]

27. Newton, P.; Schaap, B.; Fournier, M.; Cornwall, M.; Rosenbach, D.W.; DeBoer, J.; Whittemore, J.; Stock, R.; Yoders, M.; Brodnigc, G.; et al. Community forest management and REDD+. For. Policy Econ. 2015, 56, $27-37$. [CrossRef]

28. Lee-Cortés, J.; Delgadillo-Macías, J. Territorial potential as factor of development, rural management model. Agric. Soc. Desarro. 2018, 15, 191-213.

29. Aguilar, J.; Altamirano, J.; Rendón, R. Del Extensionismo Agrícola a las Redes de Innovación Rural 2010; Universidad Autónoma de Chapingo: Texcoco, Mexico, 2010; p. 282.

30. Aguilar Gallegos, N.; Olvera Martínez, J.A.; Martínez González, E.G.; Aguilar Ávila, J.; Muñoz Rodríguez, M.; Santoyo Cortés, H. La intervención en red para catalizar la innovación agrícola. Redes Rev. Hisp. Anal. Redes Soc. 2017, 28, 9-31.

(C) 2019 by the authors. Licensee MDPI, Basel, Switzerland. This article is an open access article distributed under the terms and conditions of the Creative Commons Attribution (CC BY) license (http://creativecommons.org/licenses/by/4.0/). 